\title{
Biostratigraphy of Bluish Marl Succession (Maastrichtian) in Sulaimanyia, Area, Kurdistan Region NE- Iraq
}

\author{
Khalid M. Ismael
}

\author{
Polla A. Khanaqa \\ Department of Geology \\ College of Science \\ University of Sulaimanyia
}

Kamal H. Karim

(Received 11/10/2010, Accepted 15/12/2010)

\begin{abstract}
Recently a new lithology is found at the middle part of Tanjero Formation (Maastrichtian) and consists of a bluish marl succession about $100 \mathrm{~m}$ thick in Sulaimayia area. This succession is lithologically similar to Shiranish Formation and has nearly same color and stacking pattern which didn't described in the original description in the type section of Tanjero Formation. Geographically it can be seen in Piramagroon and Sharazoor plains, Chaqchaq valley (to the northwest of Sulaimani City) and Dokan area. The biostratigraphy of this succession indicates Early Maastrichtian to Early Late Maastrichtian which includes four interval zones of:

Racemiguembelina fructicosa Interval Zone (CF4) (Early late Maastrichtian), Pseudotextularia intermedia Interval Zone (CF5) (Early Maastrichtian)

Contusotruncana contusa Interval Zone (CF6) (Early Maastrichtian)

Gansserina gansseri Interval Zone (CF7) (Early Maastrichtian)

As concerned to the affinity of this succession two possibilities can be assigned:

1-Middle part of Tanjero Formation.

2-lentils of Shiranish Formation inside Tanjero Formation.

This study prefers the first assignation as the foraminiferal assemblages show that the marly succession is not belonging to Shiranish which has, in the studied area, the age of Campanian. Another reason for this assignation is that the environment and sequence stratigraphy, tectonics of Tanjero Formation is more understandable than the first assignation (If it is included in the Shiranish Formation). The record of this new lithology and submergence of the type section of the formation under the water of Darbandikhan (dam) impose selection of a new type section or a supplementary type section for the formation either in Dokan or Chwarta areas where there are representatives of the new lithology inside the Tanjero Formation and the sections are well exposed.
\end{abstract}




\section{الطباقية الحياتية لتتابعات الطفل المزرق (الماسترختيان) في منطقة السليمانية، شمال شرق العراق}

كمال حاجي كريم

$$
\text { قبم علا ازاد خانقا كلية العلوم }
$$

خالا محمود اسماعيل

\section{الملخص}

أظهرت الدراسة الحالية تواجد تتابعات صخرية للطفل المزرق والتي تقع داخل تكوين تانجرو بسمك • . ام وتثبه تكوين شرانش من حيث المكونات الصخرية واللون والتتابع، حيث لم يتم التطرق الي هذه التتابعات في الوصف الاصلي للمقطع المثالي لتكوين تانجرو. يمكن ملاحظة هذه التتابعات في سهلي شهرزور و بيره مكروون و وادي جق جق ومنطقة الدوكان. اجريت لها دراسة طباقية حياتية

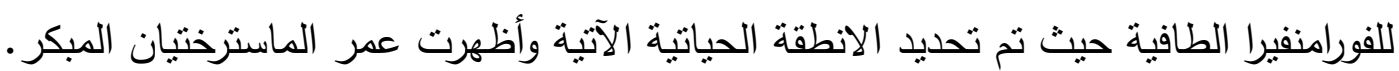

Racemiguembelina fructicosa Interval Zone (CF4) (Early late Maastrichtian) Pseudotextularia intermedia Interval Zone (CF5) (Early Maastrichtian) Contusotruncana contusa Interval Zone (CF6) (Early Maastrichtian) Gansserina gansseri Interval Zone (CF7) (Early Maastrichtian)

$$
\begin{aligned}
& \text { 1- أن تكون هذه التتابعات الجزء الوسط من تكوين تانجرو. }
\end{aligned}
$$

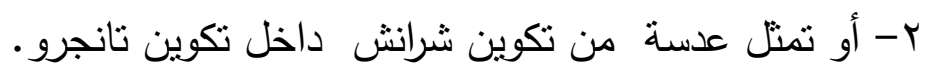

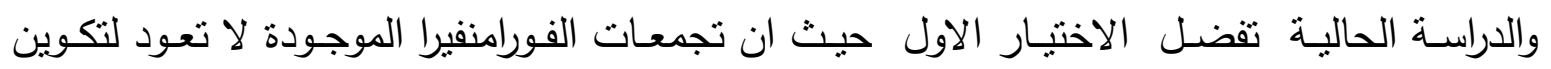

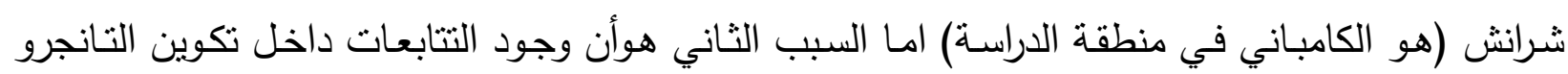

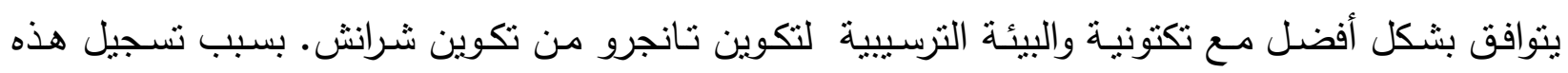

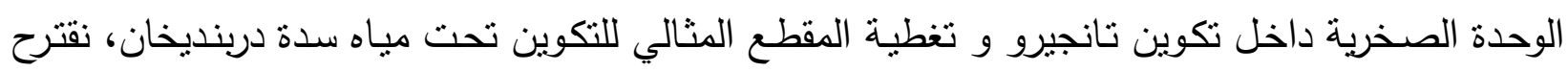

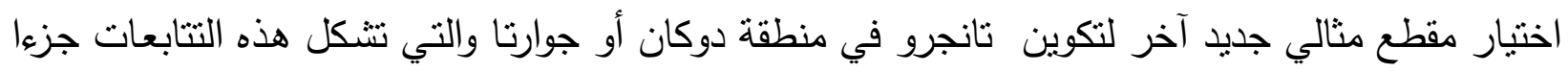

\section{INTRODUCTION}

The studied area is located in Sulaimanyia Governorate, northeastern Iraq (Fig. 1). Dunnington (1952 in Bellen et al. 1959) divided the Tanjero Formation, on the basis of lithology, in the type section, into two parts, i.e. lower and upper 
parts. He cited that the upper part consists of silty marls, siltstone, sandstone, conglomerate and sandy biogenic detrital limestone; this part is 1532 meters thick. The lower part is 484 meters thick and composed of pelagic marl with some siltstone and rare marly limestone.

The above division is based only on the lithologic variation of the type section in the Sirwan valley and had not taken into consideration in the other areas. This division is later, followed by all other researchers such as ( Buday, 1980), (Al-Rawi,1981), (Abdel-Kireem 1986a), (Jaza , 1992), (Saaddlla and Hassan, 1987).

A marly succession, about $100 \mathrm{~m}$ thick, is located at the middle part of Tanjero Formation and in many places it is, lithologically, very similar to Shiranish Formation as concerned to constituent, color and stacking pattern (Fig. 2). It can be seen in Piramagroon and Sharazoor plains, Dokan area (Qashqulley), Chaqchaq valley (Fig. 3).

In this study, this succession is called Chaqchaq Marl as it is well exposed in Chachaq valley.

This succession is wide spread in Tanjero-Balambo Subzone but as it is very soft so it is mostly covered by soil and alluvium. In these places, it is composed of light bluish white marl with occasional intercalation of thin beds of marly limestone. This succession not exist in the type section (in Sirwan valley) but its equivalent exists which consists of olive green calcareous shale.

In Chwarta area, the equivalent of the succession consists of dark green calcareous shale with thin inter beds of bluish marls which is located between sandstone succession of Tanjero Formation and limestone of Aqra lens. Most of the previous studies are conducted on those areas that are very similar to the type section; therefore they didn't deal with the succession.

The exceptions are studies of (Karim, 2004), Karim and Surdashy, (2005a and 2005b) which are assigned the succession as a middle part of Tanjero Formation. According to (Karim, 2004). occurrence of this succession, in some place and its absence in other ones is due to two reasons.

The first is that the Tanjero Formation is deposited as several fans (Jaza, 1991 and Karim, 2004), therefore the calcareous shale and sandstone are deposited in front of submarine fans and secondly, the marl and marly limestone is deposited in the areas that are located between the fans (inter-fan areas) where there are calmness and less energy of turbidity currents.

The aim of this study is to investigate the biostratigraphy to indicate the age of the Chachaq marl and to indicate the stratigraphic relation with both Tanjero and Shiranish Formation in addition to the possibility of the repetition of the succession by faulting. For this purpose 12 samples were selected for planktonic foraminiferal zonation in one outcrop section (Fig. 2). 


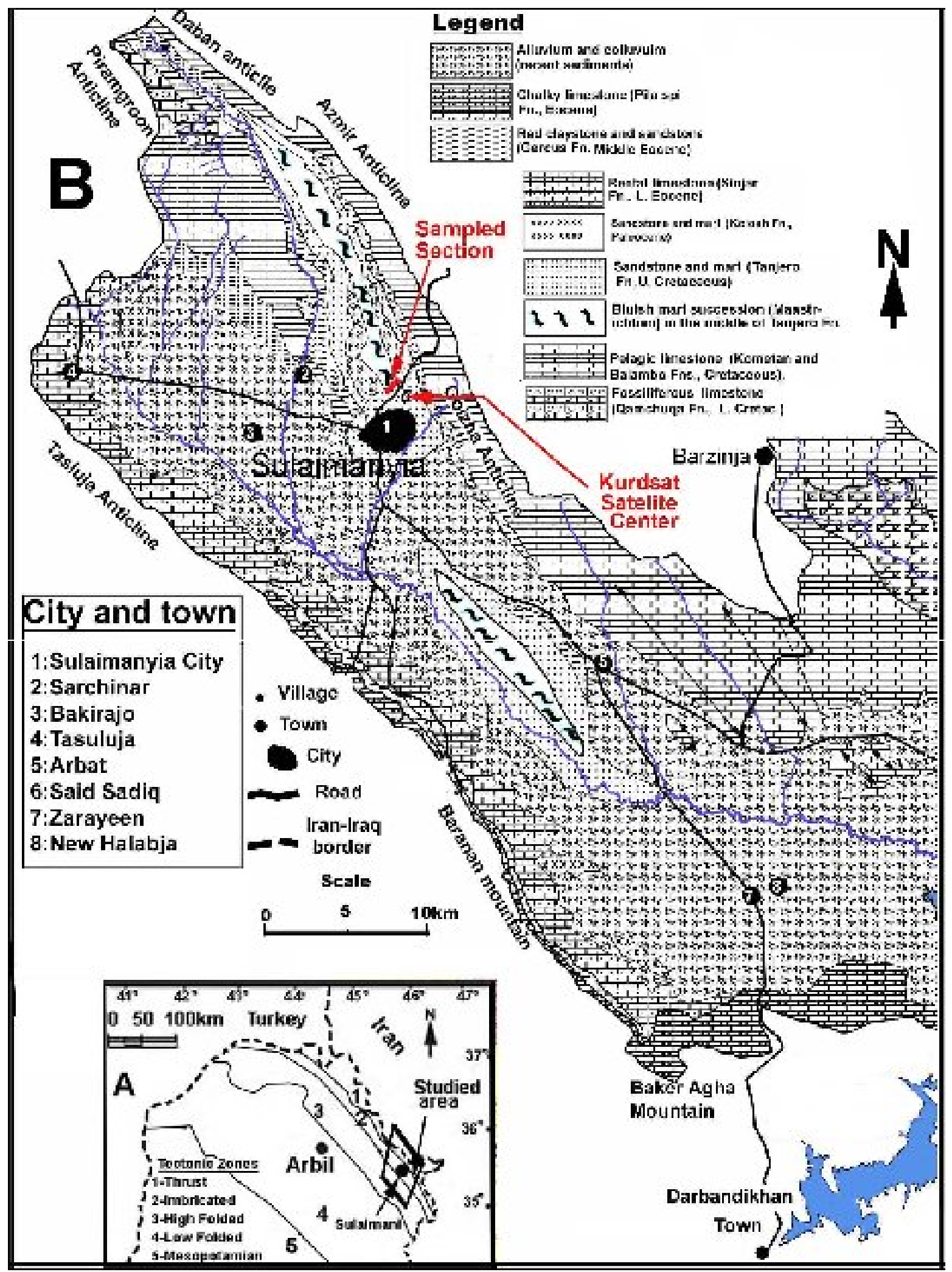

Fig. 1: Location map (A) and geological map (B) of the area around Sulaimanyia area (modified from Ali, 2008) on which the sampled section and outcrops of the new lithologies (Chaqchaq marl) of Tanjero Formation are shown. 


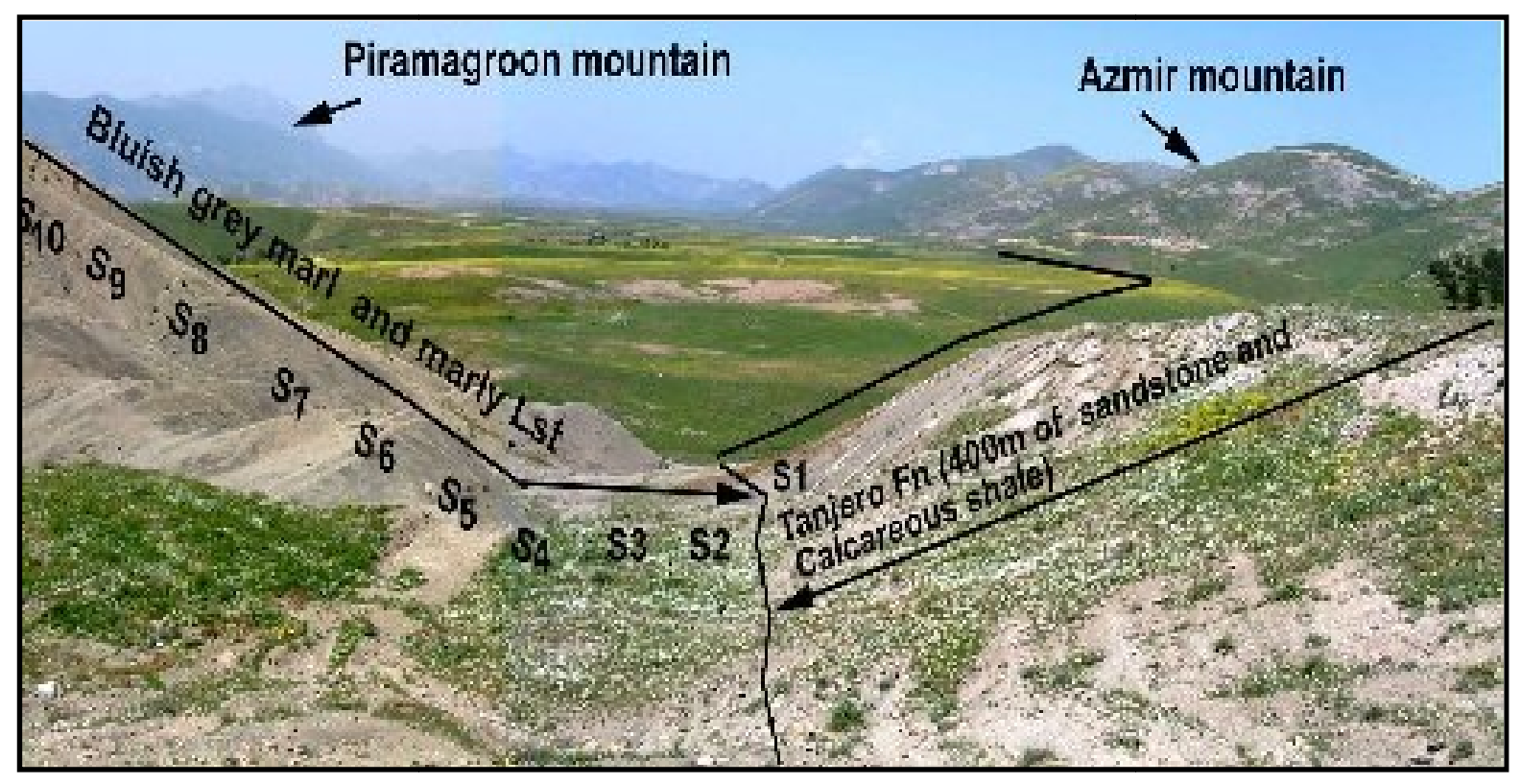

Fig. 2: The sampled section directly to the north of Kurdsat Satellite Center (North of Sulaimanyia).

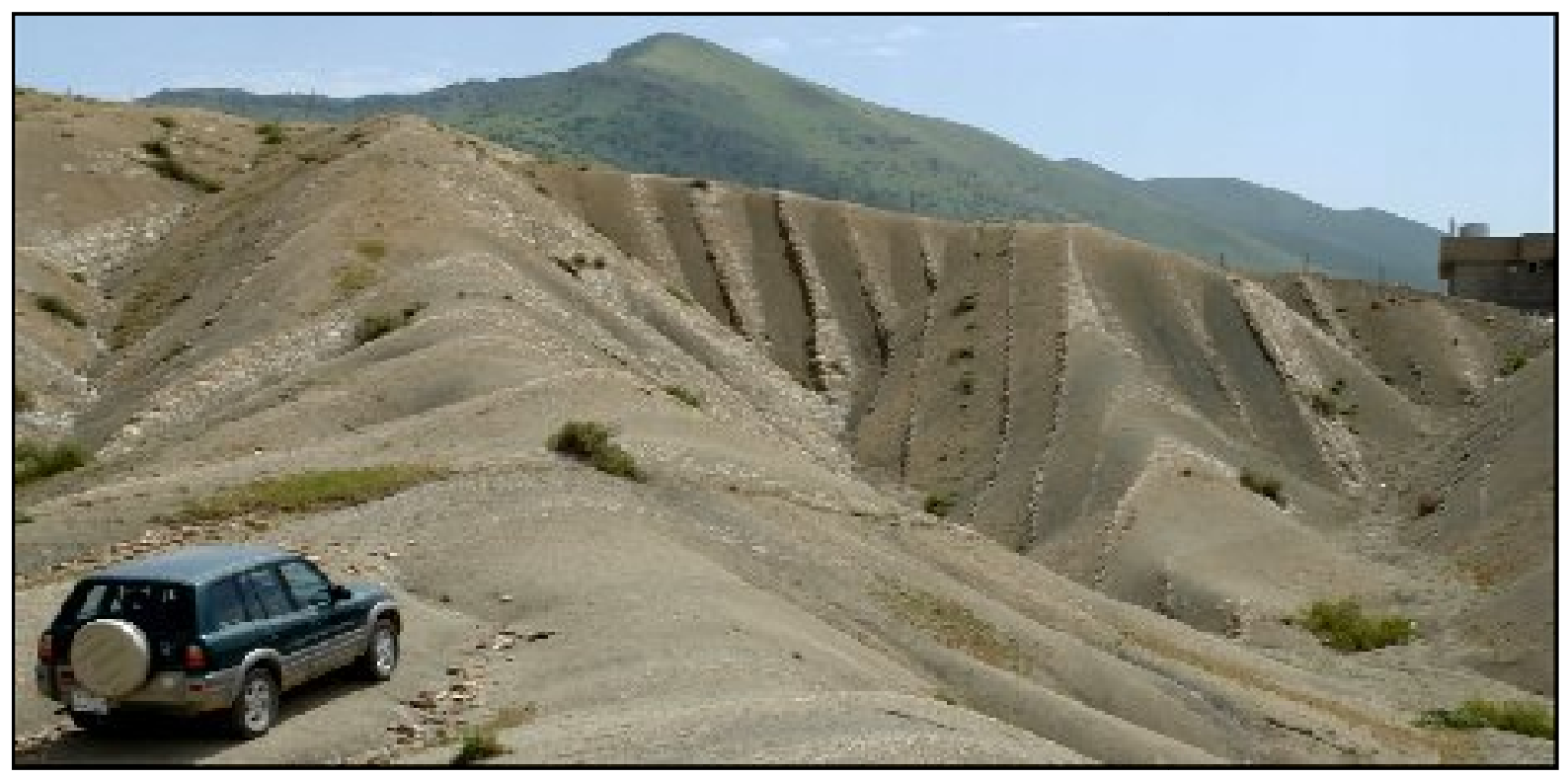

Fig. 3:Typical lithology and stacking pattern of the relatively competent and incompetent bluish marl successions (Chaqchaq Marl) which is located directly to the southwest of Qulqula village. 


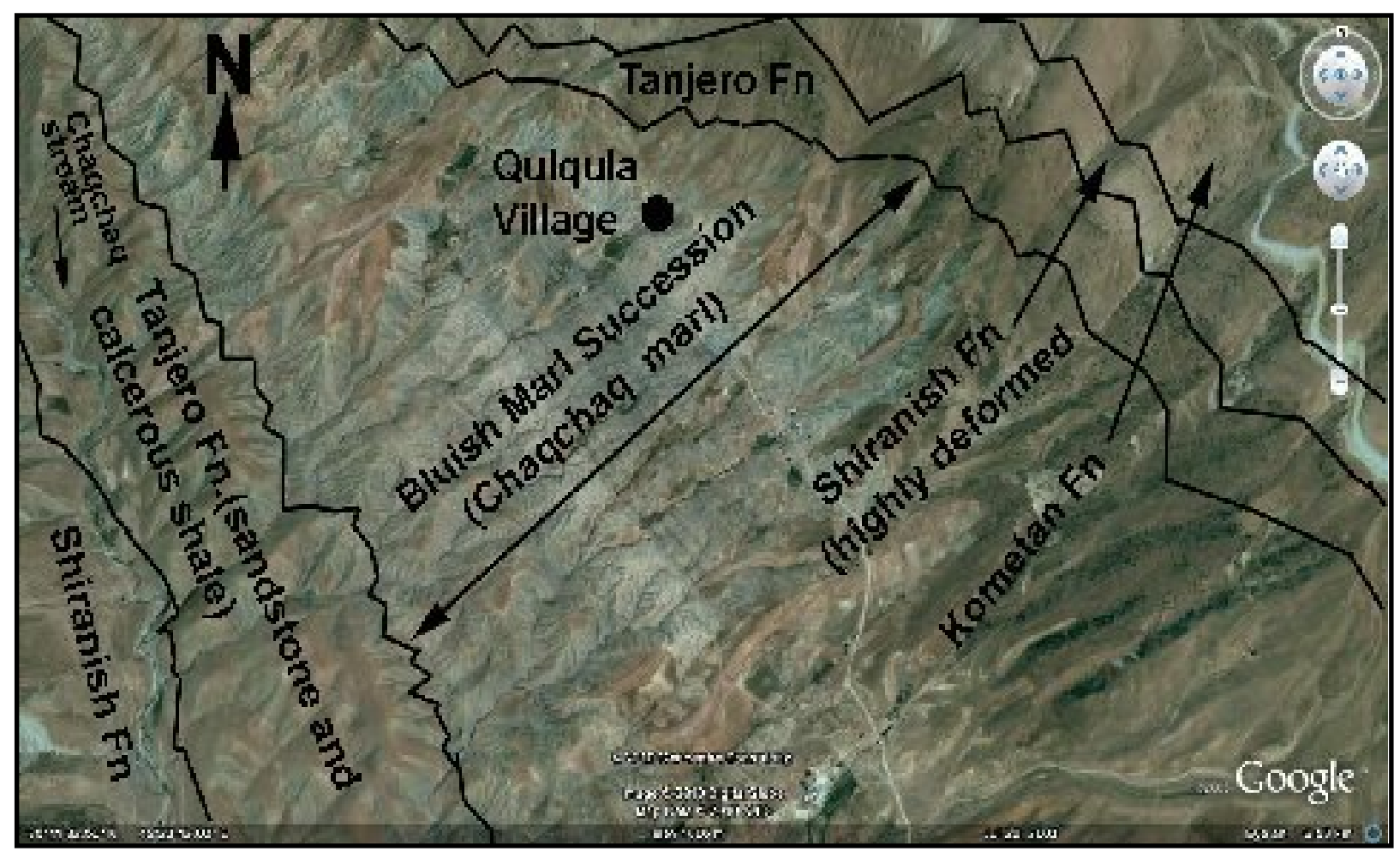

Fig. 4: Chachaq valley (directly to the northeast of Sulaimaniya city) in which the succession is well exposed.

\section{BIOSTRATIGRAPHY}

The samples are taken from an outcrop section which provided abundant well preserved foraminifera. These include high diversity of Globotruncanids, Rugoglobigerinids, Globigerinelloids and Heterohelicids planktonic foraminifera with moderate calcareous and rare agglutinated benthonic foraminifera (Fig. 4).

The foraminifera occur continuously in the studied succession generally shows continuous sedimentary sequence without any interruptions. Fifty seven planktonic foraminiferal species belonging to nineteen genera were recorded (Fig. 5).

The planktonic foraminifera show the best indication for typical Tethyan fauna type. They are used for biozonation of the sediments in tropical/subtropical regions by (Li and Keller, 1998a), (Keller, 2004), (Abramovich et al., 2002), (Abramovich and Keller, 2003), ( Samir 2002), (Obaidalla, 2005) and (Sharbazheri 2007, 2008, 2010). These studies are used exclusively as the biostratigraphic framework in this study. (Li and Keller, 1998a) subdivided the Maastrichtian zonal scheme into nine Cretaceous Foraminiferal (CF) zones labeled CF9 to CF1, from the base to the top. They calibrated their ranges to the paleomagnatic time scale in the DSDP Site 525A and on Tunisian sections by (Li and Keller, 1998b). 
The Diagnosis and biozonation that are used in this study follow that of (Georgescu, 1996, 2002), and (BouDagher- Fadel, et al.,1997).

The biostratigraphic correlation of the studied section is based on planktonic foraminiferal zonations (Figs. 6,7) which shows a comparison between the biostratigraphic zones established in this study with other equivalent of the commonly used planktonic zonal scheme. The biostratigraphic zones are described from the bottom to the top of the section as follows:

\section{Gansserina gansseri Interval Zone (CF7)}

The Gansserina gansseri (or CF7 zone) was introduced by (Bronnimann , 1952) in (Samir, 2002) as Globotruncana gansseri Zone and placed in the Early Maastrichtian of Trinidad. In present study, the base of this biozone is not recorded and the top of the zone is marked by the FAD of Contusotruncana contusa (Cushman), (Plate 1, Figs. a, b). Most of the workers in the zonal scheme placed Gansserina gansseri zone informally at the middle- lower Maastrichtian (Abramovich, et al.,2002, Samir, 2002, Maestas et al., 2003, Al-Mutwali and Al-Jubouri 2005, Chacon and Martin 2005, Sharbazheri, 2007, 2008, 2010) (Figs.7,6). ( Obaidalla , 2005) placed this zone at the base of Late Maastrichtian and (Maestas et al,. 2003) placed this zone at Late Campanian- Early Maastrichtian. This zone cover abundant occurrence of the nominate species for $7 \mathrm{~m}$.in Tanjero Formation and $10 \mathrm{~m}$ of bluish marl succession. In addition to the index species, the planktonic assemblages of this zone recorded in the (Fig. 5) and its age is Middle Early Maastrichtian.

\section{Contusotruncana contusa Interval Zone (CF6)}

Dalbeiez (1955) in (Samir, 2002) proposed the Globotruncana contusa Zone for the Late Maastrichtian of Tunisia. Biostratigraphically it is located at the interval between the FAD of Contusotruncana contusa (Cushman), at the base and last appearance (LAD) of Globotruncana linneiana (d'Orbigny) at the top (Plate 1, Figs. f). In present study this Zone (CF6) covers an interval of 50m and provided an assemblage of planktonic foraminifera which totally resembles that of the underlying Gansserina gansseri Zone (CF7), except for the first appearance of Contusotruncana contusa (Cushman), Globotruncanita angulata Tilev ,Globotruncana dupeublei Caron et al., Rugotruncana subcircumnodifer (Gandolfi), Contusotruncana plicata White, Contusotruncana walfishensis Todd, Globotruncanella pschadae (Keller), Pseudotextularia deformis (Kikoine), Pseudotextularia intermedia (De Klasz, Gublerina cuvillieri Kikoine, Hedbergella holmdelensis Olsson.

As defined herin, the present biozone (CF6) is correlatable with the zone recorded by ( $\mathrm{Li}$ and Keller, 1998 b), (Abramovich et al., 2002), (Samir, 2002). (Sharbazheri, 2008, 2010), (Abawi et al., 1982) and (Abdel-Kareem, 1986 a and b) correlated the zone to the lower part of Rosita contusa Zone in the Northeast of Iraq. (Premoli-Silva and Sliter, 1995, 1999), (Premoli-Silva et al., 1998) in Italy. 
(Abdel-Kareem and Samir, 1995) in Egypt. It is correlated with middle part of Gansserina gansseri Zone of (Al-Mutwali,1996), (Hammoudi, 2000), ( Al-Mutwali and Al-Jubouri, 2005), (Chacon and Martin, 2005). Iraq and other different localities of the world (Robaszynski et a l., 1984), (Caron , 1985), (Hont and Keller, 1991), (Maestas et al., 2003), (Obaidalla, 2005), (Figs. 7, 6). Magnetochron records by (Li and Keller, 1998 a) of this biozone shows the age estimation of the time span from (69.56 - 69.06) Ma with estimated absolute time span of $500 \mathrm{Ky} / 50 \mathrm{~m}$ ages based on magnetochron ages with $10 \mathrm{Ky} / \mathrm{m}$ with moderate rate of deposition (Fig. 6). Age: Late Early Maastrichtian.

\section{Pseudotextularia intermedia partial range Zone (CF5)}

In the present study Pseudotextularia intermedia Zone or (CF5) is defined by the LAD of the Globotruncana linneiana (d' Orbigny) at the base and the FAD of Racemiguembelina fructicosa (Egger) at the top. (Nederbragt, 1991) originally introduced this biozone as the interval from the FAD of Planoglobulina acervulinoides at the base and the FAD Racemiguembelina fructicosa at the top.

In the present study, the application agreed with the definition of (Li and Keller, 1998b). The interval of this zone is $28 \mathrm{~m}$ thick, besides the planktonic foraminiferal species enduring from the underlying biozones, some species shows their first appearance, e.g. Pseudotextularia intermedia (De Klasz),Globigerinelloides subcarinata Bronnimann, Globigerinelloides bolli pessango.Abathomphalous mayaroensis Bolli, and Hedbergella deleroiensis Carsey.

Due to high similarities of foraminiferal occurance, the present zone (CF5) is equivalent to that of ( $\mathrm{Li}$ and Keller, $1998 \mathrm{a}, \mathrm{b}$ ), (Abramovich et al., 2002), (Samir, 2002) , (Sharbazheri, 2008, 2010) it is mostly equivalent to the upper part of Gansserina gansseri Zone recorded in the North, Northeast of Iraq and different regions of the world (Al-Mutwali and Al-Jubouri, 2005), (Al-Mutwali, 1996), (Hammoudi, 2000), (Caron, 1985), (Ubaidalla, 2005), (Robaszynski, et al., 1984) and (Hont and Keller, 1991) and it is equivalent to the upper part of Glt.contusa Zone of (Abawi, et al., 1982) and (Abdel-Kareem, 1986), and Glt .contusa-R . fructicosa Zone of Premoli (Silva and Sliter, 1995, 1999), (Abdel-Kareem and Samir, 1995) (Figs. 7, 6).

The Pseudotextularia intermedia Zone spans about 0.73Myr (69.06 - 68.33), $730 \mathrm{Ky} / 28 \mathrm{~m}$ estimating absolute ages based on magnetochron ages with 26 $\mathrm{Ky} /$ meter of moderate rate of deposition (Fig. 6). Age: Late Early Maastrichtian.

\section{Racemiguembelina fructicosa Interval Zone (CF4) part}

Racemiguemblina fructicosa Zone or (CF4) is introduced by (Li and Keller, 1998 a, b) as a biostratigraphic interval between FAD of Racemiguembelina fructicosa (Egger) at the base and the FAD of Pseudoguembelina hariaensis at the top. Only the lower part of this zone is recorded in the upper part (10m thick) of 
the marly succession and continued to the Tanjero Formation (sample No.12) to the FAD of Pseudoguembelina hariaensis Nederbragt (not studied).

Most of the workers in the zonal scheme placed Racemiguemblina fructicosa Zone at the Early Late Maastrichtian, (Keller et al., 1995), (Li and Keller, 1998b), (Premoli Silva, 1999), (Abramovich, et al., 2002), (Samir, 2002) and (Obaidalla, 2005) (Sharbazheri, 2007, 2008 and 2010)).

As defined above, the present biozone (CF4) is correlatable with the lower part of A. mayaroensis of (Abawi, et al., 1982), (Robaszynski, et al., 1984), (Caron, 1985), (Abdel-Kareem, 1986) and (Premoli- Silva and Sliter, 1995-1999) (Figs. 5, 6). This zone covers abundant occurrence of the nominate species along $35 \mathrm{~m}$ thick In addition to the index species, Racemiguemblina fructicosa (Egger), the planktonic foraminiferal assemblages of this zone include well preserved of 40 species which shown in stratigraphic range chart of the studied section (Fig. 5).

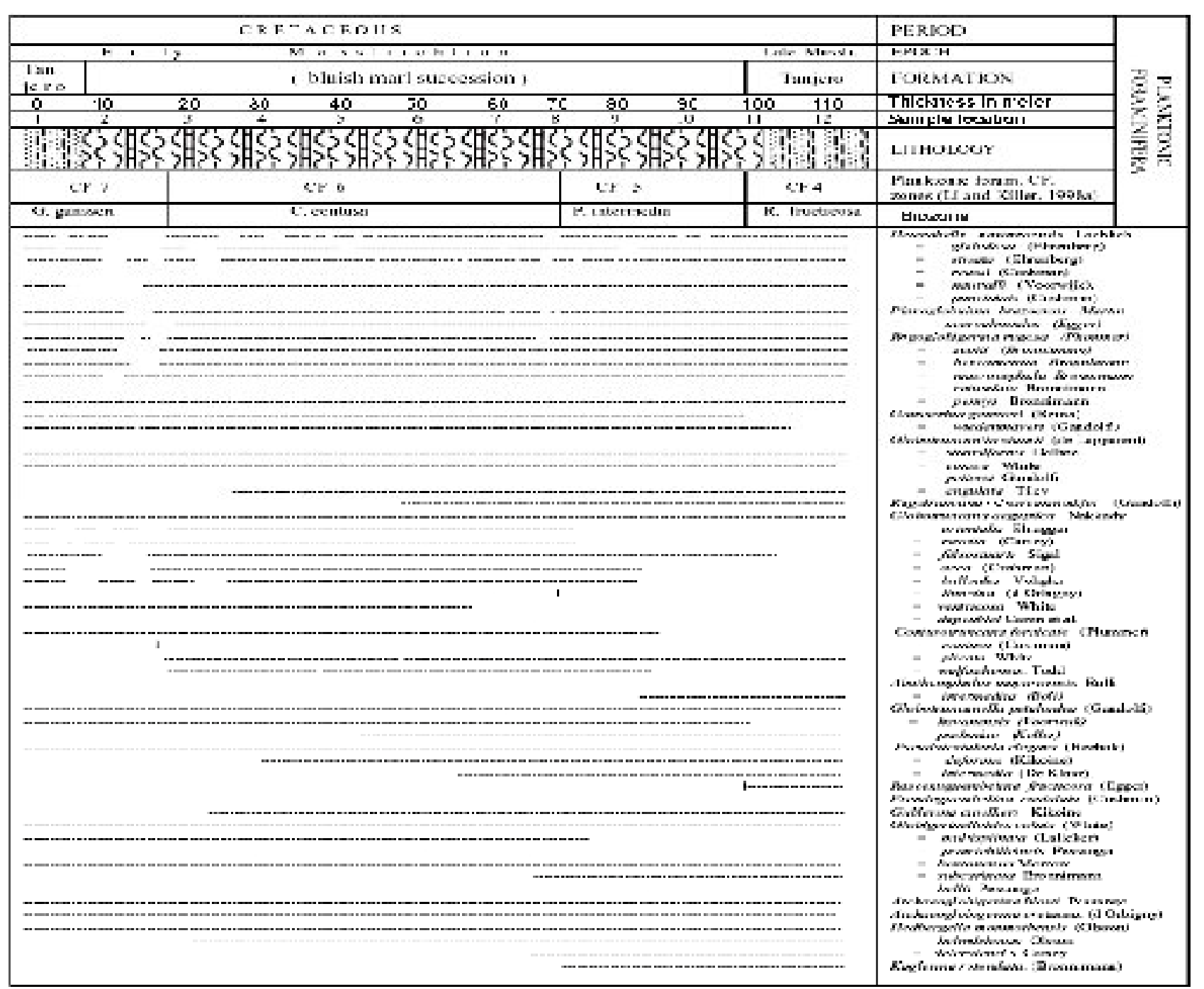

Fig. 5: Stratigraphic range chart of planktonic foraminifera of the bluish Chaqchaq Marl of the Kurdsat section, Sulaimanyia area. 


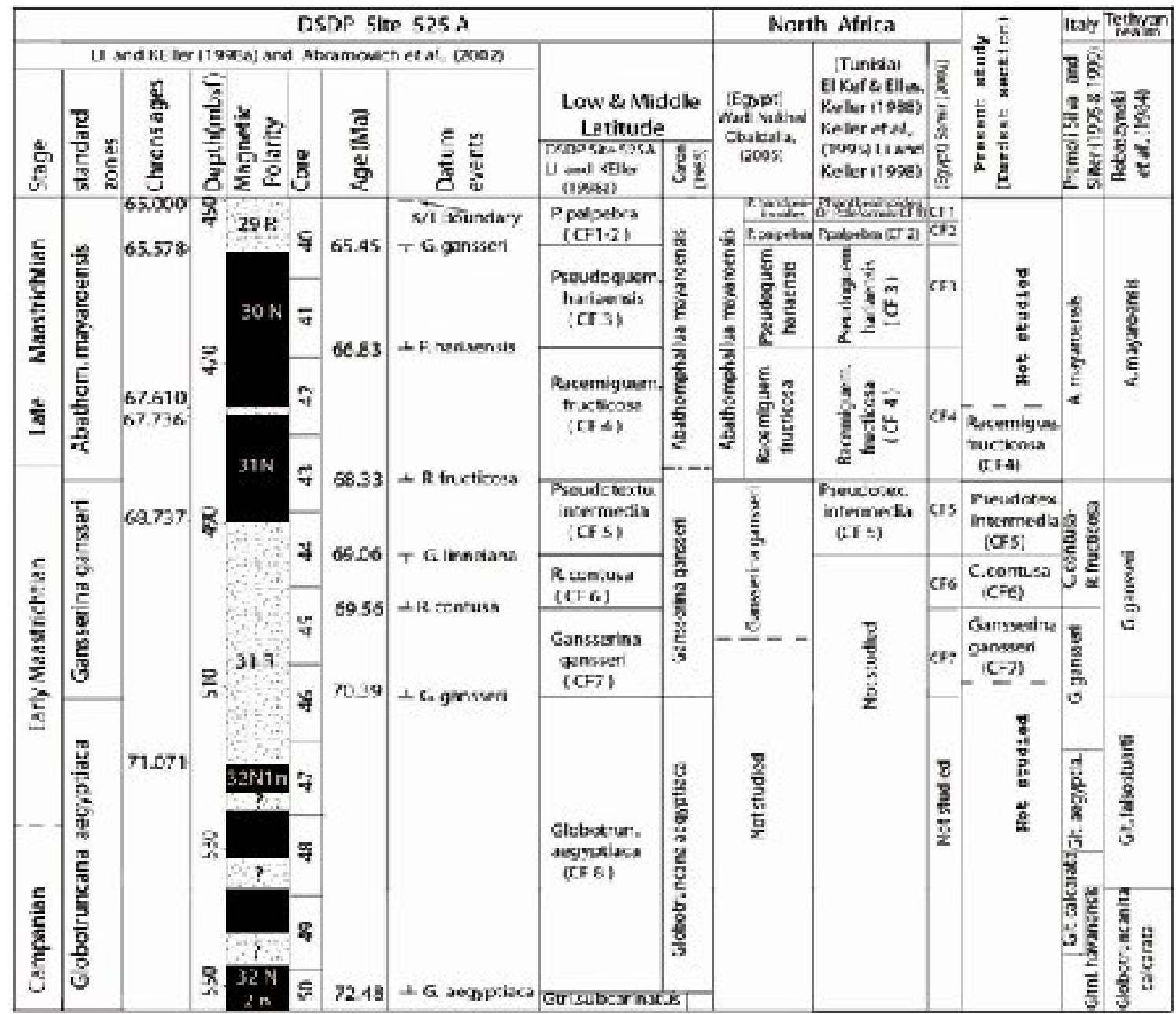

Fig. 6: Correlation chart showing the proposed biostratigraphic zones of Kurdsat with the Planktonic foraminiferal zonation commonly used in low, middle latitudes. The present proposed zonation based on DSDP Site 525A, (by Li and Keller, 1998 a) and (Abramovich, et al., 2002) in the new zonal scheme. The age of planktonic foraminiferal datum events is shown. (Modified from different authors).

\section{Requirement of introduction a new type section and a supplementary reference section of the formation}

According to North American Commission on Stratigraphic Nomenclature (1983), reference section is very valuable in definition and revision of geologic units. It is convenient to indicate and define new type section for Tanjero Formation for the following reasons:

First: the water of Darbandikhan reservoir covers the original type section, especially its contact with Shiranish Formation. The type section runs along the northwestern band of the Sirwan River (upstream of Diala River). In this connection the North American Commission on Stratigraphic Nomenclature (1983) is permitted to assign neostratotype when the stratotype is covered. 
Second: the lithology of the type section is not the representative of the formation (as proved by the authors) and only representative of Sirwan Valley. Even in the Tanjero valley, from which the name came, the formation has very different lithology as includes the bluish marl succession in the middle part.

Third: the Tanjero valley (from which the name is derived) is about $20 \mathrm{~km}$ far from the Sirwan valley. Therefore, according to the above-mentioned Commission, the Sirwan valley section (type section) does not demonstrate regional validity as concerned to lithology and naming. Moreover, the supplementary reference sections, according to the commission, are often designated to illustrate the diversity or heterogeneity of a defined unit or some critical feature not evident or exposed in the stratotype. When a new type section is selected in the Chuarta area or around Sulaimaniya City its lithology will stand for at least $80 \%$ of the outcrops of the formation. This new section will show the different parts of the formation and the environment in addition to sequence stratigraphy can be deduced easily. According to sequence stratigraphy, the new sections will give clear subdivision of the formation into its system tract.

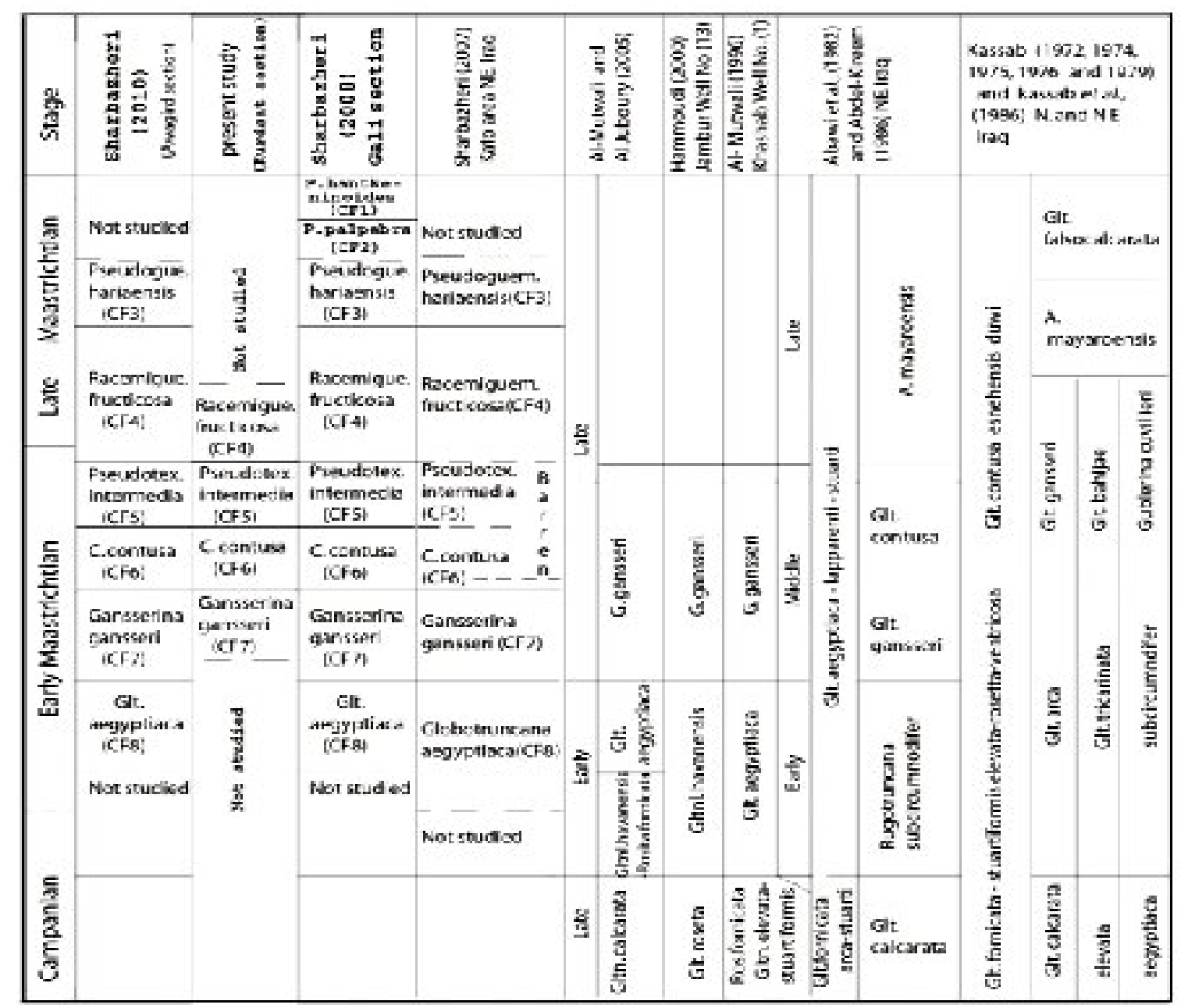

Fig.7:Correlation chart showing the proposed biostratigraphic zones of Kurdsat section with the Planktonic foraminiferal zonation commonly used in Iraq. 


\section{CONCLUSIONS AND RECOMMENDATION}

1- Fifty eight planktonic foraminiferal species belonging to nineteen genera have been recorded from the bluish marl succession.

2- Four Planktonic Foraminiferal biostratigraphic zones have been detected in the studied section represent Gansserina gansseri Interval Zone (CF7), Contusotruncana contusa Interval Zone (CF6), Pseudotextularia intermedia Partial Range Zone (CF5), Racemiguembelina fructicosa Interval Zone (CF4), and they display Early Maastrichtian-Early Late Maastrichtian age.

3- The planktonic foraminifera occur continuously in the sedimentary succession of the studied section shows continual in deposition without any interruptions.

4- The exposed bluish marl succession (Chaqchaq Marl) has special monotonous, conventional lithologic character differs from Tanjero Formation which extends geographically for more than $80 \mathrm{~km}$ and it has mapable extend and thickness which reaches about $100 \mathrm{~ms}$ in Kurdsat section, with relevant feasible geologic age of Early Maastrichtian about $1.5 \mathrm{My}$ duration.

5- Consequently the authors recommend the supplementary type section of Tanjero Formation in the studied area as a new formal lithologic description to display all lithologic components and characters according to international stratigraphic code.

\section{REFERENCES}

Abawi, T. S., Abdel-Kireem, M. R. and Yousef G. M., 1982. Planktonic Foraminiferal Stratigraphy of the Shiranish Formation, Sulaimaniah- Dokan Region NE Iraq. Revista Espanola de Micropaleontologia, Vol. 14, No. 1, pp. $153-164$.

Abdelm Kireem, M. R., 1986a. Contribution to the Stratigraphy of the Upper Cretaceous and Lower Tertiary of the Sulaimaniya - Dokan region, Northeastern Iraq. N. Jb. Geol. Paleont. Abh. Vol. 172, No. 1, pp. 121 - 139. Abdel Kireem, M. R., 1986b. Planktonic Foraminifera and Stratigraphy of the Tanjero Formation (Maastrichtian), Northeastern Iraq. Micropaleontology, Vol. 32, No. 3, pp. $215-231$. 
Abdel-Kireem, M. R. and Samir, A. M., 1995. Biostratigraphic Implications of Maastrichtian-Lower Eocene Sequence at the North Gunna Section, Farafra Oasis, Western Desert, Egypt. Marine Micropaleontology. Vol. 26, pp. 329 - 340.

Abramovich, S. and Keller, G., 2003. Planktonic Foraminiferal Response to the Latest Maastrichtian Abrupt Warm Event: A case Study from South Atlantic DSDP Site 525A. Marine Micropaleontology. Vol. 48, pp. 225 - 249.

Abramovich, S. Keller, G. Adatte, T. Stinnesbek, W. Hottinger, L. Stueben, D. Berner, Z. Ramanivosa, B. and Randriamanantenasoa, A., 2002. Age and Paleoenvironment of Maastrichtian to Paleocene of the Mahajanga Basin, Madagascar: a Multidisciplinary Aapproach. Marine Micropaleontology. Vol. 47, pp. 17 - 70.

Ali, S. A., 2008. Geology and Hydrogeology of Sharazoor-Piramagroon Basin in Sulaimani Area, Northeastern Iraq. Unpublished PhD. Thesis, University of Bilgrad, Sirbia, 330p.

Al-Mutwali, M. M., 1996. Planktonic Foraminiferal Biostratigraphy of Shiranish Fn. Khashab well No. 1, Hemren Area. Northeastern Iraq. Jour. Geol. Sci. Iraq, Vol. 7, No. 1, pp. 129 - 136.

Al-Mutwali, M. M. and Al-Jubouri, F. N., 2005. Litho and Biostratigraphy of Shiranish Formation (Late Campanian-Late Maastrichtian) In Sinjar Area, Northwestern Iraq. Rafidain Journal of Science, Vol. 16, No. 1, Geology, Special Issue. pp. 152 - 176.

Al-Rawi, I. K., 1981. Sedimentology and Petrography of Tanjero Clastic Formation From North and NE, Iraq. Unpub. Ph.D. Thesis, University of Baghdad, 295p.

Bellen, R. C. Van, Dunnington, H. V., Wetzel, R. and Morton, D., 1959. Lexique Stratigraphique, Interntional. Asie, Iraq, Vol. 3c. 10a, 333 p.

Bou Dagher-Fadel. M. K, Banner. F. T, and Whittaker. J. E., 1997. The Early Evolutionary History of Planktonic Foraminifera. Chapman and Hall. London. 289p., 15 Figs., 52 plate.

Buday, T., 1980. Regional Geology of Iraq: Vol. 1, Stratigraphy: I. I. M. Kassab and S. Z. Jassim (Eds) GEOSURV. Pub. 445p.

Caron, M., 1985. Cretaceous Planktic Foraminifera. in Bolli, H.M., Saunders ,J.B. and Perch-Nielsen,K.,(Eds.) Planktonic Stratigraphy, pp. 17 - 87, (37 Figs.) Cambridge Univ. Press.

Chacon. B. and Martin-Chivelet. J., 2005. Major Paleoenvironmental Changes in the Campanian to Paleocene Sequence of Caravaca (Subbetic Zone, Spain). Journal of Iberian Geology, Vol. 31, No. 2, pp. 299 - 310.

Georgescu, M. D., 1996. Santonian - Masstrichtian Planktonic Foraminifers (Globigerinelloididae, Hedbergellidae, Globotrucanidae and Rugoglobigerinidae) in the Romanian Black Sea offshore. Micropaleontology. Vol. 42, No. 4, pp. 305 - 333, Text-Figures 1-7, Plates 1 - 12. 
Georgescu, M. D., 2002; Available at: http:// services. chronos. org/ guideplankforam/ index. htm. An Interactive Guide to Planktonic Foraminifera; A. Cretaceous Ttaxa.

Hammoudi, R. A.,2000. Planktonic Foraminiferal Biostratigraphy of the Shiranish Fn. (Late Cretaceous) in Jambur Well No.13 Northern Iraq. Raf. Jour. Sci. Vol. 11, No. 4, pp. 50 - 58.

Hont, S. and Keller, G., 1991. Some Patterns of Planktonic Foraminiferal Assemblage Turnover at the Cretaceous / Tertiary Boundary. Marine Micropaleontology.Vol. 17, pp. 77 - 118.

Jaza, I. M, 1992. Sedimentary Facies Analysis of the Tanjero Formation in Sulaimaniya District, NE-Iraq. Unpubl. M. Sc. Thesis, Salahaddin University, $121 \mathrm{p}$.

Jenkins, D. G. and Murray, J. W., 1981. Stratigraphic Atlas of Fossil Foraminifera. Ellis Horwood Limited Publ. 310 p., (48 Figs.), (66pls.).

Karim, K. H., 2004. Basin Analysis of Tanjero Formation in Sulaimaniya area, NE-Iraq. Unpublished PhD. Thesis, University of Sulaimani, 135p.

Karim, K. H. and Surdashy, A. M., 2005a. Paleocurrent Analysis of Upper Cretaceous Foreland Basin: a Case Study for Tanjero Formation in Sulaimanyia Area, NE-Iraq, Journal of Iraqi Science,Vol. 5, No.1, pp. 30 - 44.

Karim, K. H. and Surdashy, A. M., 2005b. Tectonic and Depositional History of Upper Cretaceous Tanjero Formation in Sulaimanyia Area NE - Iraq. JZS, Vol. 8, No. 1, pp. 47 - 62.

Kassab, I. I. M., 1974a. The Genus Heterohelix (Foraminiferida) from Northern. Iraq. Journal of Geological Society of Iraq, Vol. VII , pp. 75 - 94

Kassab, I. I. M., 1975c. Planktonic Foraminifera Range in the type Tanjero Formation Upper Campanian-Maastrichtian) of N. Iraq. Journal of Geological Society of Iraq, Vol. 8, pp. 73 - 86. Kassab, I. I. M., 1975d. The genus Globigerinelloides from Northern. Iraq. Journal of Geological Society of Iraq, Vol. 8, pp. 8 - 105.

Kassab, I. I. M., 1976. Some Upper Cretaceous Planktonic Foraminiferal Genera from Northern Iraq. Micropaleontology, Vol. 22, No. 2, pp. 215 -238, pls. 1 - 4,

Kassab, I. I. M. Al-Omari, F. S. and Al- Safawee, N. M., 1986. The Cretaceous Tertiary Boundary in Iraq (Represented by the Subsurface Section of Sasan Well No.1, N.W. Iraq) Journal of Geological Society, Iraq, Vol. 19, No. 2, pp.73 - 86.

Keller, G., 2004. Low Diversity, Late Maastrichtian and Early Danian Planctonic Foraminiferal Assemblages of the Eastern Tethys. Journal of Foraminiferal Research, Vol. 34, No. 1, pp. 49 - 73.

Li, L. and G. Keller., 1998a. Maastrichtian Climate, Productivity and Faunal Turnover in Planctonic Foraminifera in South Atlantic, DSDP Sites 525A and 21. Marine Micropaleontology. Vol. 33, pp. 55 - 86. 
Li, L. and G. Keller., 1998b. Diversification and Extinction in Campanian Maastrichtian Planktonic Foraminifera of Northwest Tunisia. Ecol. Geol. Helv., Vol. 91, pp. $75-107$.

Maestas, Y. Macleod, K. G. Douglas, R. Self-Trail, J. and Ward, P. D., 2003. Late Cretaceous Foraminifera, Paleoenvironments, and Paleoceanography of theRosario Formation, San Antonio Del Mar, Baja California, Mexico. Journal of Foraminiferal Research, Vol. 33, No. 3, pp. 179 - 191,

Obaidalla, N. A., 2005. Complete Cretaceous/Paleogene (K/P) Boundary Section at Wadi Nukhul, Southwestern Sinai, Egypt: Inference from Planktonic Foraminiferal Biostratigraphy. Revue de Paleobiologic, Geneve (2005) Vol. 24, No. 1, pp. 201 - 224.

Premoli-Silva, I. and Sliter, W. V., 1995. Cretaceous Planktonic Foraminiferal Biostratigraphy and Evolutionary Trends from the Bottaccione Ssection. Gubbio, Italy :Paleontographia Italica. Vol. 82, pp. 1 - 89.

Premoli-Silva, I. and Sliter, W. V., 1999. Cretaceous Paloceanography: Evidence from Planktonic Foraminiferal Evolution, in Barrera, Geological Society of America Special Paper 332, pp. 301 - 328.

Premoli-Silva, I. Spezzaferi. S. and D Angelantonio, A., 1998. Cretaceous Foraminiferal Bio-Isotope Stratigraphy of Hole 967E and Paleogene Planktonic Foraminiferal Biostratigraphy of Hole 966E, Eastern Mediterranean. Robertson, A, H, F., Emeis, K.C., Richter, C., and Camerlenghi, A. (Eds) Proceedings of Ocean Drilling program, Scientific Result, Vol. 160, pp. 377 - 394.

Robaszynski, F., Caron, M., Gonzalez, D. J. M. and Wonders, A. A.H., 1984. Atlas of Late Cretaceous Globotruncanids Revue de Microp., Vol. 26, No. 3 - 4, pp. 145- 305.

Saadalla, A. and Hassan, A. H. 1987. Sedimentological Study of Selected Section of Tanjero Formation. Iraqi Journal of Science, Vol. 28, No. 3- 4, pp. 483 - 506.

Samir, A. M., 2002. Biostratigraphy and Paleoenvironmental Changes in the Upper Cretaceous-Early Paleogene Deposits of Gabal Samara Section, Southwestern Sinai, Egypt. Egypt. Jour. Paleontol., Vol. 2, pp.1 - 40.

Sharbazheri, K. M., 2007. Aging of Unconformity within Tanjero Formation in Chwarta area Northeast of Iraq (Kurdistan Region). Iraqi Journal of Earth Science, Vol. 7, No.1, pp. 37 - 54.

Sharbazheri, K. M., 2008. Biostratigraphy and Paleoecology of the Cretaceous/Tertiary Boundary in the Sulaimani Region, Kurdistan, NE-Iraq. Unpublished $\mathrm{PhD}$. Thesis, University of Sulaimani, 200p.

Sharbazheri, K. M., 2010. Planktonic Foraminiferal Biostratigraphy of the Upper Cretaceous Reddish to Pale Brown Transitional Succession in Smaquli Area, Northeast Iraq (Kurdistan Region). Iraqi Bulletin of Geology and Mining Vol. 6, No.1, 2010, pp. 1 - 20. 


\section{PLATE - 1}
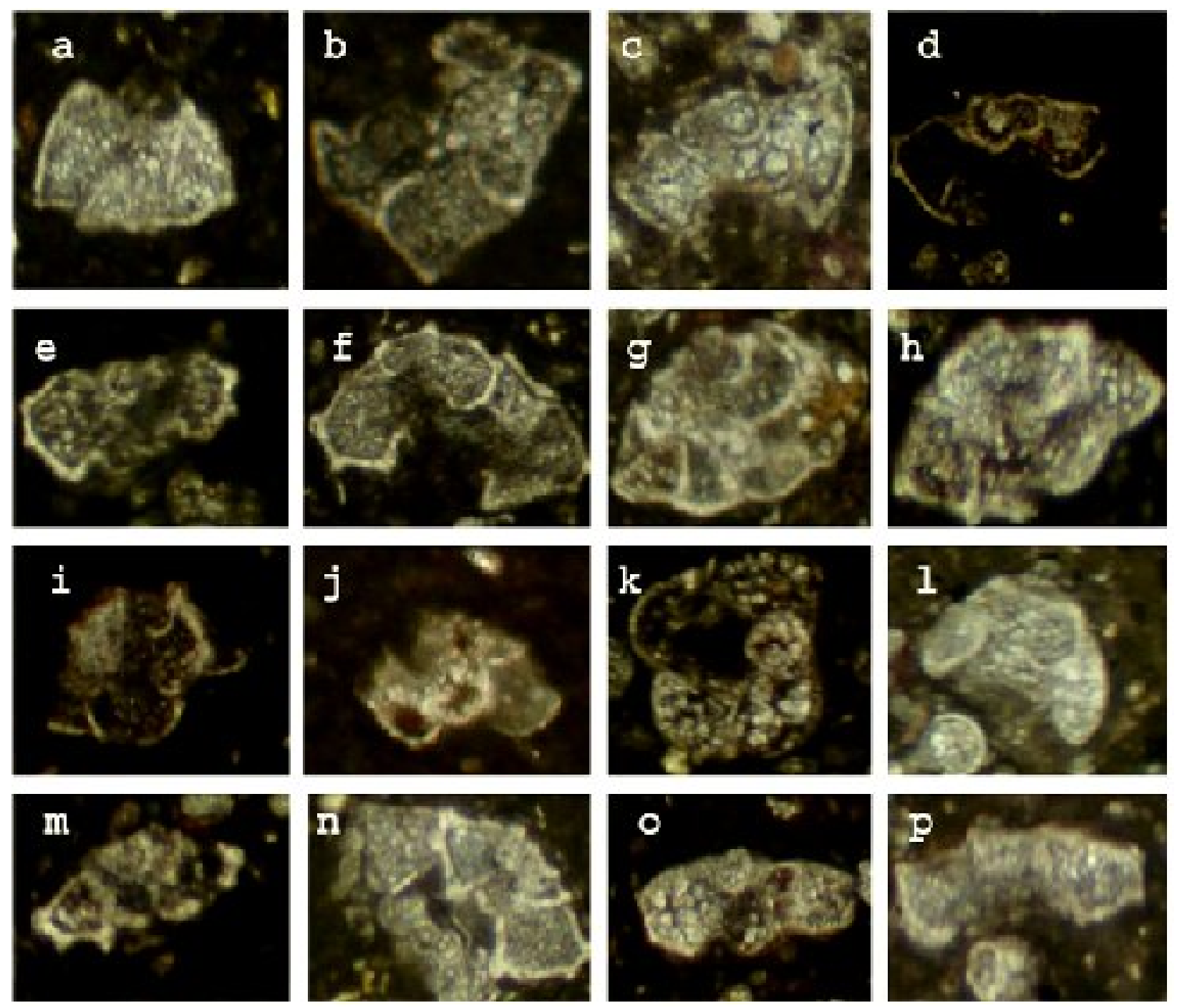

Figs. a, b Gansserina gansseri (Bolli), 100X, bluish marl succession, Early Maastrichtian, Kurdsat, Specimen from G. gansseri Zone.

Figs. c Gansserina wiedenmayeri (Gandolfi), bluish marl succession, Early Maastrichtian, Kurdsat, Specimen from G. gansseri Zone.

Figs. d ,e Globotruncana aegyptiaca Nakkady, 100X, bluish marl succession Early Maastrichtian, Kurdsat, Specimen from G. gansseri Zone.

Fig. f Contusotruncana contusa (Cushman), 100X, bluish marl succession, Early Maastrichtian, Kurdsat, Specimen from Contusotruncana contusa Zone.

Figs. g, h Globotruncanita conica White, 100X, bluish marl succession, Early Maastrichtian, Kurdsat, Specimen from Contusotruncana contusa Zone.

Figs. I, j Contusotruncana walfischensis. Todd, bluish marl succession, Early Maastrichtian, Kurdsat, Specimen from Contusotruncana contusa Zone. 
Figs. k, 1 Contusotruncana sp. 100X, bluish marl succession, Early Maastrichtian, Kurdsat, Specimen from Contusotruncana contusa Zone.

Figs. m, n Globotruncana orientalis. El-Naggar, 100X, bluish marl succession, Early Maastrichtian, Kurdsat, Specimen from Contusotruncana contusa Zone.

Figs. o, p Globotruncana linneiana (d Orbigny), 100X, bluish marl succession, Early Maastrichtian, Kurdsat, Specimen from Contusotruncana contusa Zone.

\section{PLATE - 2}
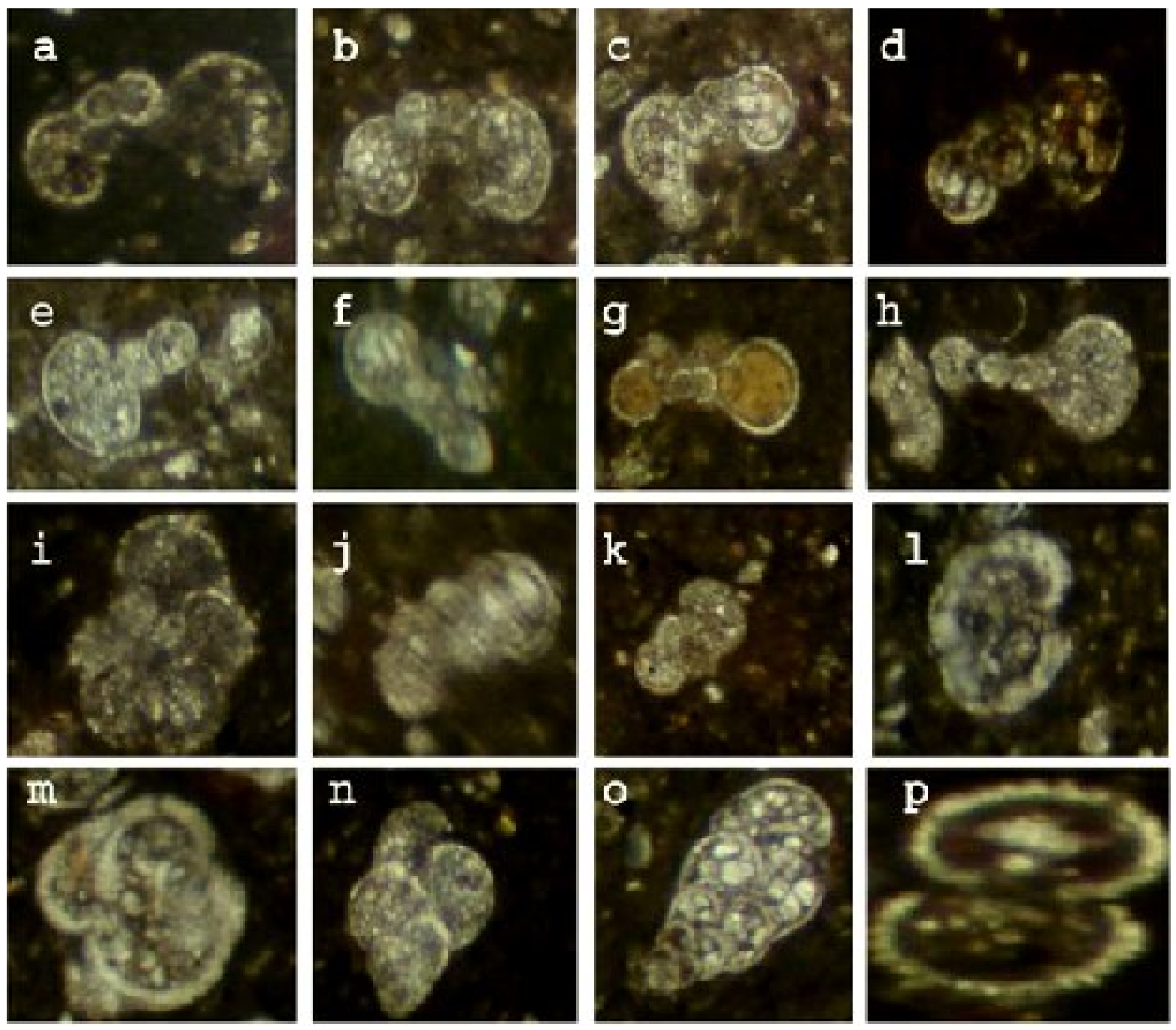

Fig. a Hedbergella deleroiensis Carsey 100X, bluish marl succession, Early Maastrichtian, Kurdsat, Specimen from $C$. contusa Zone.

Fig. b Hedbergella monmuthensis (Olsson), 100X, bluish marl succession, Early Maastrichtian, Kurdsat, Specimen from C. contusa Zone.

Figs. c, d Hedbergella holmdelensis Olsson, 100X, bluish marl succession, Early Maastrichtian, Kurdsat, Specimen from C. contusa Zone.

Fig. e Globigerinelloides bentonensis Morrow 100X, bluish marl succession, Early 
Maastrichtian, Kurdsat, Specimen from C. contusa Zone.

Fig. f Globigerinelloides subcarinata.(Bronnimann), 100X, bluish marl succession,

Early Maastrichtian, Kurdsat, Specimen from C. contusa Zone.

Figs. g, h Globigerinelloides bollii Pessango 100X, bluish marl succession,

Early Maastrichtian, Kurdsat, Specimen from G. gansseri Zone.

Figs. i, j Rugoglobigerina rugosa. (Plummer), 100X, bluish marl succession, Early

Maastrichtian, Kurdsat, Specimen from P.intermedia Zone.

Fig.k Rugoglobigerina macrocephala. Bronnimann. 100X, bluish marl succession, Early Maastrichtian, Kurdsat, Specimen from $P$. intermedia Zone

Figs. 1, m Kuglerina rotondata. (Bronnimann). 100X, bluish marl succession,

Early Maastrichtian, Kurdsat, specimen from G. gansseri Zone.

Fig. n Heterohelix globulosa.(Ehrenberg), 100X, bluish marl succession, Early Maastrichtian, Kurdsat, specimen from G. gansseri Zone.

Fig. o Heterohelix punctulata. Cushman, 100X, bluish marl succession, Early Maastrichtian, Kurdsat, Specimen from R. fructcosa Zone.

Fig. p Pseudotextularia elegans. (Rzehak), 100X, bluish marl succession, Early Maastrichtian, Kurdsat, Specimen from $C$. contusa Zone.

\section{PLATE - 3}
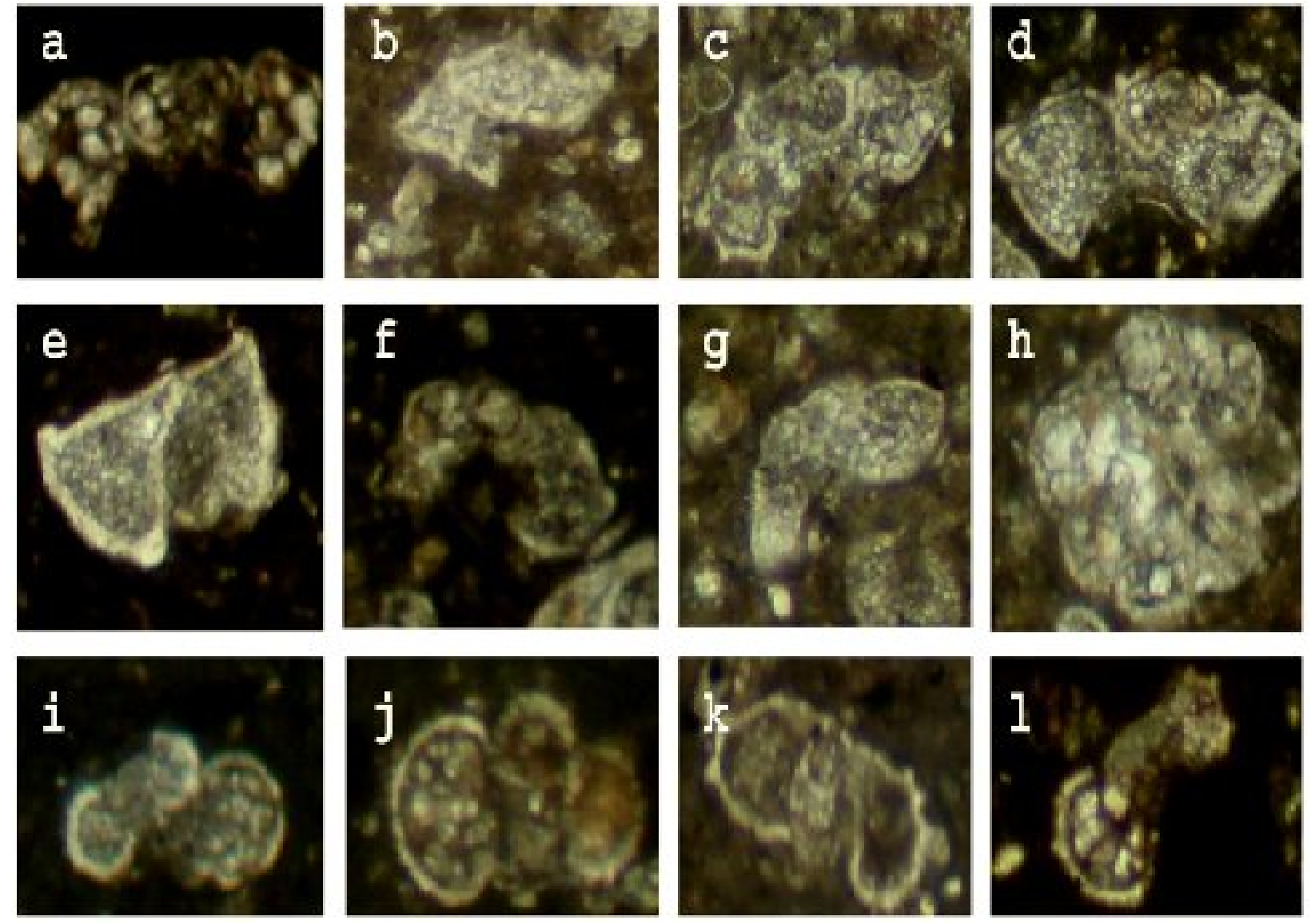
Fig. a Globotruncana bulloides, Vohgler, 100X, bluish marl succession, Early Maastrichtian, Kurdsat, Specimen from $C$. contusa Zone.

Fig. b Globotruncana falsostuarti. Sigal, 100X, bluish marl succession, Early Maastrichtian, Kurdsat, Specimen from G. gansseri Zone.

Figs. c, d Globotruncana arca. (Cushman). 100X, bluish marl succession, Early

Maastrichtian, Kurdsat, Specimen from $C$. contusa Zone.

Fig. e Globotruncanita angulata, Tilev. 100X, bluish marl succession, Early Maastrichtian, Kurdsat, Specimen from G. gansseri Zone.

Fig. f Globotruncanella havanensis (Voorwijk), 100X, bluish marl succession, Early Maastrichtian, Kurdsat, Specimen from P.intermedia Zone.

Fig. g Globotruncanella petaloidea (Gandolfi). 100X, bluish marl succession, Early Maastrichtian, Kurdsat, Specimen from P.intermedia Zone.

Fig. h Racemiguembelina fructicosa (Egger) 100X, bluish marl succession, Early Maastrichtian, Kurdsat, Specimen from R. fructcosa Zone.

Figs. i , j Archaeoglobigerina blowi. Pessango, 100X, bluish marl succession, Early Maastrichtian, Kurdsat, Specimen from G. gansseri Zone.

Figs. k, 1 Archaeoglobigerina cretacea. (d Orbigny), 100X, bluish marl succession, Early Maastrichtian, Kurdsat, specimen from G. gansseri Zone. 